Bhatter College Journal of Multidisciplinary Studies

Approved by the UGC (Serial No. 629, Subjects: Education, Broad category: Social Sciences)

ISSN 2249-3301, Vol. VII, Number 1, 2017

Article url: www.bcjms.bhattercollege.ac.in/v7/n1/mc-en-v7-01-01.pdf

Article DOI: 10.25274/bcjms.v7n1.mc-en-v7-01-01

\title{
Study on effects of shopping orientation on the consumers buying online in Punjab
}

\author{
Pankaj Jain ${ }^{1} \&$ Dr. Gautam Bansal ${ }^{2}$ \\ ${ }^{1}$ Research Scholar I.K. Gujral Punjab Technical University.Email:pankaj_jain88@ymail.com \\ ${ }^{2}$ Dean, Department of Commerce (PCTE).Email: gautam@pcte.edu.in
}

\begin{abstract}
Buying something online 15 years back seemed something very difficult for an Indian Consumer but development of the World Wide Web has resulted in the creation of a new form of business i.e. electronic retailing (e-tailing) or web-shopping. Consumers these days are buying all the stuff from personal grooming to Groceries, apparels, mobile phones etc online. Thus, customers' involvements in online purchasing have become an important trend. As such, it is vital to identify the determinants of the customer online purchase intention. The aim of this research is to evaluate the impacts of shopping orientations on the customer online purchase intention. A total of 523 respondents were asked questions on their shopping orientations and their products purchase. Efforts were put in to explore the linkage between their shopping orientation and the products they purchased. The findings revealed that impulse purchase intention, quality orientation, brand orientation, online trust and prior online purchase experience were positively related to the customer online purchase intention.
\end{abstract}

Keywords: Shopping Orientation, online purchase intention.

\subsection{Introduction to $\mathrm{E}$-Commerce}

The rapid development of Internet technology has enabled Indian consumers to purchase products or services from the web-retailers and search product information over the Internet in seconds. Business-to-consumer e-commerce, or commerce between companies and consumers is the subset of e-business focused on transactions that include buying/selling online, digital value creation, virtual marketplaces and storefronts, and new distribution channel intermediaries. It is the second largest and the earliest form of e-commerce. Its origins can be traced to online retailing (or etailing). India is expected to become the world's fastest growing e-commerce market, driven by healthy investment in the sector and rapid increase in the number of internet users. As per a report on India's B2C Ecommerce 2016 BY E Commerce Foundation approximately 255 million people use internet and out of that 83 million people shop online out of which $33 \%$ population uses smartphones. With a population of more than 1000 million and only around $25 \%$ people using internet just look at the enormous opportunity which is there in front of the online business houses if they can rightly exploit this situation. 


\subsection{Shopping Orientation}

A consumer's approach to the act of shopping is referred to as shopping lifestyle or shopping orientation. The basic premise of shopping orientations is that people take many different approaches to the act of shopping. Thus, this type of analysis determines the variety of shopping styles that individuals adopt and how these styles relate to purchase intentions. Shopping orientation basically demonstrates that whether consumers prefer to shop under an experiential or a taskfocused orientation. For our study we have taken following 5 orientations to establish the relationship with the purchase intention of consumers buying online.

1.2.1 Impulse Purchase Orientation: These are those types of shoppers who feel an urge to shop instantly as soon as they see something interesting or a sale is there. They cannot stop themselves from buying something which is not even useful to them or they don't even require it.

1.2.2 Brand Orientation: These shoppers are brand lovers and loyal to those brands only. They won't shift from the brands whatever happens. These types of consumers are most important for any company because once they win them these will remain with the company till they are shopping. Price of the other brands won't impact them.

1.2.3 Quality Orientation: These types of consumers are quality oriented. They will always look for a better quality then their previous purchases irrespective of the fact which brand is available. They also go for unbranded products if they perceive that their quality is better than the branded ones.

1.2.4 Emotional Orientation: These types of shoppers are basically looking for relaxation and pleasure after making an online purchase. They don't look out for brands or prices or quality but they look out for emotional quotient in a product. If they feel that after buying a particular product it will give them a sense of accomplishment they will go for same.

1.2.5 Value/ Price Orientation: Consumers who are always looking for value for money, discounts and always comparing various products fall under this category. These shoppers are always on a look for bulk discounts and offer's which induces them to purchase online.

\subsection{Need of Study}

Backed by massive discounts and the growing use of Smartphone's, the Indian e-commerce marketplace is poised to grow 36\% during the 2015-20, a new report has said. "India's workforce comprises of young customers who have less time for going out and shopping at regular brick and mortar stores. Such a scenario creates potential for online shopping in a market as huge as India. In this E era where everything is going online for ease of customer's and seller's it becomes important to understand why there has been a sudden shift in traditional means of buying the products and services. Consumers these days are more prone to buying goods online rather than going to shops and fulfill their shopping requirements. In such a scenario this study will help us in understanding the orientation of these consumers and also provides a platform for Indian and multinational companies in exploring the potential consumers of their products.

2.2 Objectives: For research paper titled "To study the effects of shopping orientation of the consumers buying online in Punjab" following objectives were set:

1 To study customer profile of online buyer's in Punjab. 
2 To explore shopping orientation of these consumers in Punjab.

\section{Literature Review}

Jiradilok (2014) et al investigated upon customer satisfaction that leads to online purchase intention for all online users, conversant online purchasers and new online purchasers. The study revealed that people mostly value assurance and empathy as the most important dimensions. This finding was applicable for both types of internet users that are users with knowledge in purchasing and users with no experience in purchasing.

Cheema (2013) et al studied factors that manipulate online shopping intentions. The findings disclose that apparent ease of use and supposed enjoyment are the factors that affect online shopping purpose. Unexpectedly, the effect of supposed usefulness was not noteworthy on online shopping intention

Connolly and Bannister (2008) stated that Irish consumer's trust in internet shopping is the result of particular factors, which relates to the vendor's professed integrity, and the vendor's professed capability. The earlier encompasses communal experience of trust, while the second encompasses the technical background of trust. Both of these factors are within the control of vendor.

Phang et al (2010) investigated the effects of the demographic variables of age, gender, education and income based on the theories of media sincerity and consumer trait and attachment. They concluded that e-commerce marketers must recognize consumer's fundamental shopping motivations and needs in order to successfully satisfy them. They establish that demographic variables as such don't impact the client intention of what they want to purchase as most of the times they do surfing and then compare the prices with offline stores.

YinFah et al (2013) studied difference in shopping orientation and its association with the online purchase purpose among university students. Respondents' regularity of online purchasing was completely related to the occurrence of online browsing. Of the five types of shopping orientations, convenience category of shopping orientation had the strongest relation to online purchasing purpose.

Kwek et al (2010) identified the determinants of the customer online purchase objective. They found that urged purchase intent, quality orientation, brand name orientation and convenience orientation are completely related to the customer online purchase goal. It was also discovered that ease of buying orientation is the most vital contributor to the online purchase purpose.

Vijayasarathy (2003) stated that Shopping orientations are helpful in the study of patronage performance including store faithfulness, brand reliability, in-home shopping, and out-shopping. Paper further illustrated that home, economic, and neighbouring shopping orientations are associated to online shopping intentions. Product types, based on price tag and tangibility, do not have a moderating influence on the relationship between shopping orientations and intentions to shop using the Internet, but do have a direct effect on the latter. And, the incremental involvement of demographic indicators in predicting online shopping objective is negligible.

Brown et al (2003) stated that in spite of the prevalent belief that Internet shoppers are mainly motivated by convenience, the authors showed empirically that consumer's primary shopping orientations had no considerable impact on their inclination to purchase products online. Factors that were more likely to control purchase intention included product type, previous purchase, and, to a smaller extent, sex. 


\section{Research Methodology}

Area of the Research: The study was conducted in 4 cities of Punjab State namely Ludhiana, Amritsar, Gurdaspur and Jalandhar based on the total population residing in these cities.

Research Design: The study was conducted following a descriptive design, where efforts were made to describe the characteristics of the people along with products and services purchased by them through e-retailing.

Population: In this study population consisted of all individuals who had access to internet, searched for products online and experienced buying a product or service electronically at least once in Punjab.

Sample Size: Total Sample size for the study was 523 based on e-responses and hand filled questionnaires.

Sampling Unit: The sampling unit was every single individual who had experience of buying the product electronically in Punjab.

\section{Data Analysis and Interpretation:}

\subsection{Demographic Profiling of Respondents:}

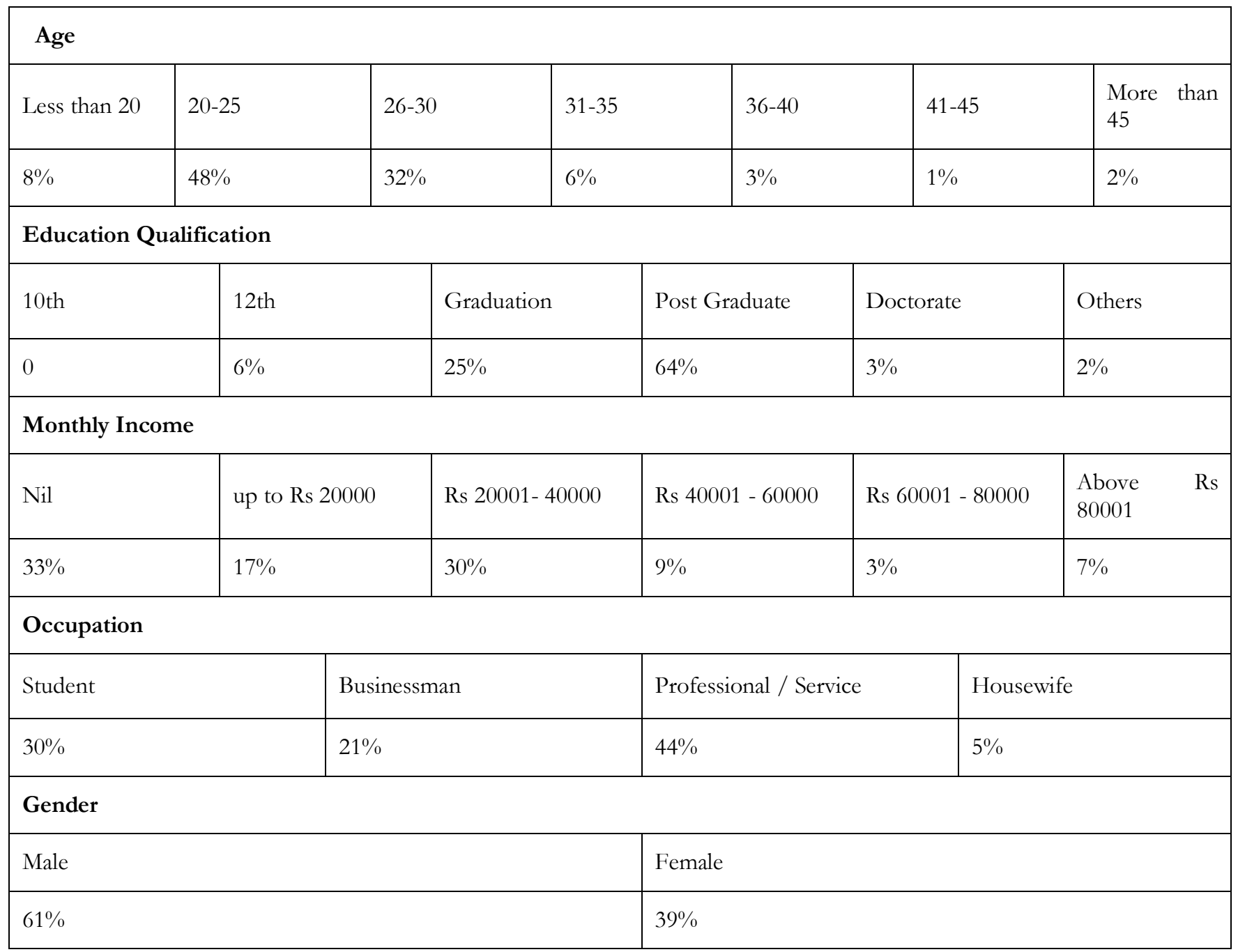


5.2 Graph showing time since buying online

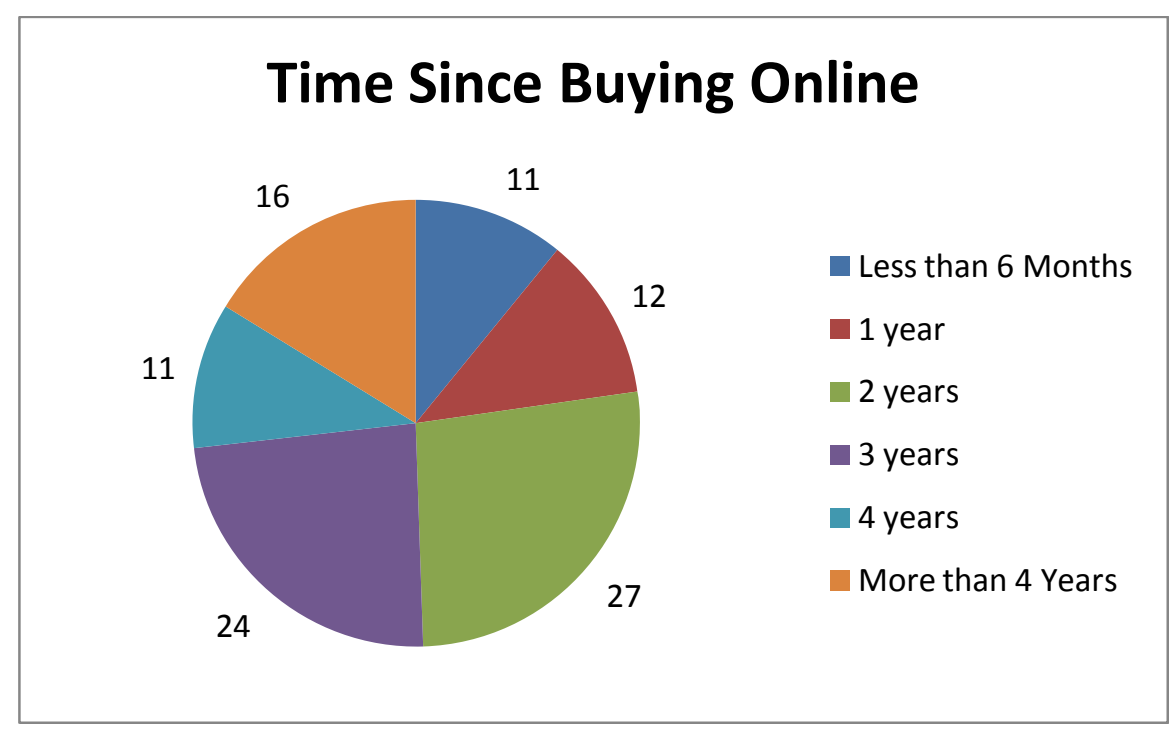

Interpretation: From above graph it can be seen that more than $75 \%$ of the respondents have been purchasing online from last 2 years which clearly indicates that online buying has been accepted well by the consumers and they are showing interest in buying multiple items online.

\subsection{Graph showing Frequency of Buying Online}

\section{Frequency of Buying Online}

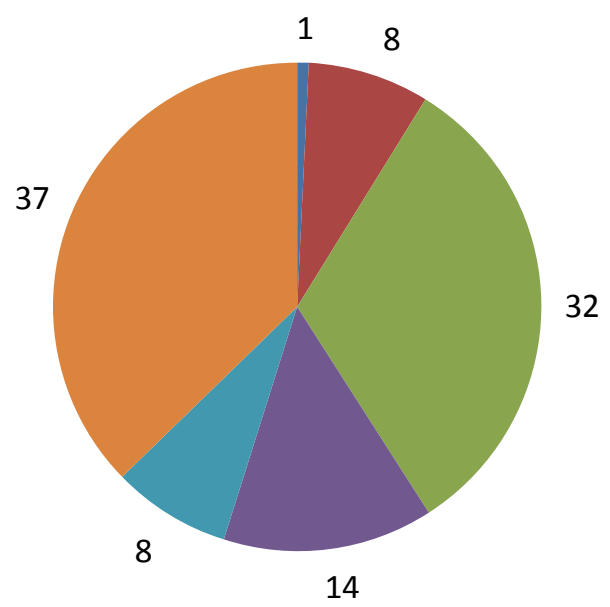

Daily

- Once a week

Once a month

Every 6 Months

During Online Sale

When Required

Interpretation: From above graph it can be concluded that the myth that sales are more during online sales is wrong because majority of the respondents buy online whenever they require something followed by the category who buy once a month. Very few individuals buy on daily basis. 
5.4 Graph showing Source of Awareness - Online Shopping

\section{Source of Awareness - Online Shopping}

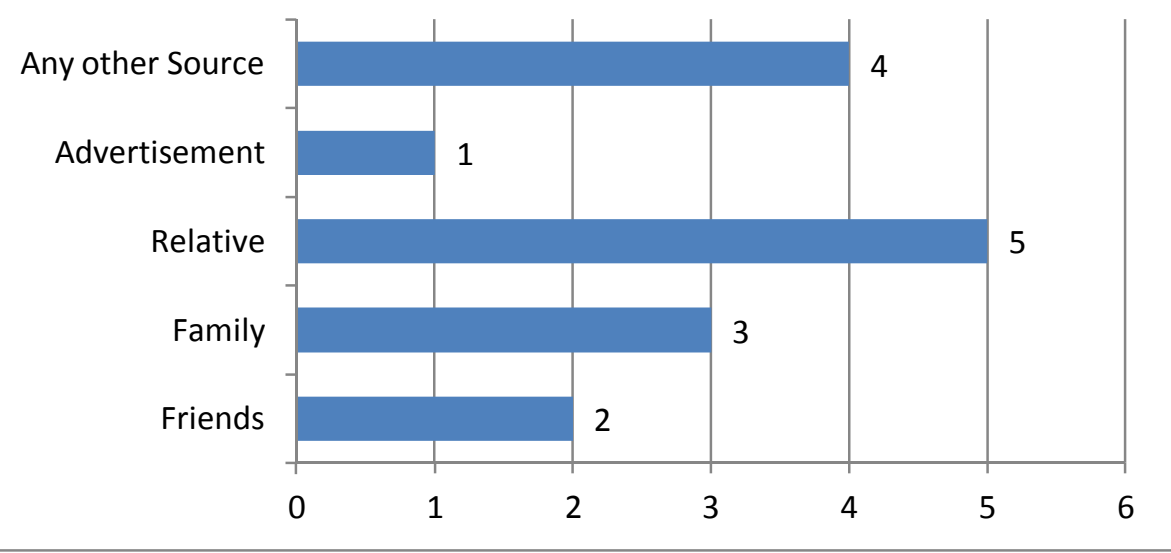

Interpretation: From above graph it is clearly visible that consumers came to know about online shopping through the advertisements that companies are running. Another very important source of information is through word of mouth by friends which they share through social media platforms.

5.5 Graph showing Amount Spent - Online Buying

\section{Amount Spent - Online Buying}

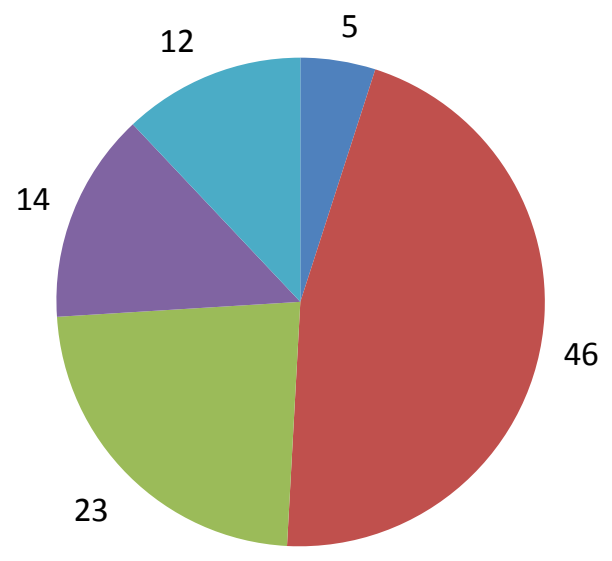

- Less Than 500

- 501-1500

1501-2500

- 2501-3500

More than 3500

Interpretation: From above graph it can be analyzed that almost $50 \%$ of the respondents spend upto Rs 1500 on an average and only 12\% spend more than Rs 3500 from this we can interpret that still consumers in India are not willing to purchase items with a higher value and they like to play 
safe by not ordering products with a higher value. The main reason for same is the trust on quality of products.

\subsection{Shopping Orientation Statement:}

\begin{tabular}{|c|c|c|}
\hline Orientations & & $\begin{array}{l}\text { Mean } \\
\text { Score }\end{array}$ \\
\hline \multirow{5}{*}{$\begin{array}{l}\text { Impulse } \\
\text { Purchase }\end{array}$} & $\begin{array}{c}\text { When my intention is to only browse through the website, I end up making a } \\
\text { purchase. }\end{array}$ & 3.41 \\
\hline & When I purchase products suddenly from website, I feel relaxed. & 3.5 \\
\hline & $\begin{array}{l}\text { When there are bulk discounts on offer I feel an impulse to buy the } \\
\text { product/services. }\end{array}$ & 3.87 \\
\hline & Females are more impulsive then men while buying online. & 3.75 \\
\hline & $\begin{array}{c}\text { Whenever I do a planned purchase online I also end up buying unplanned } \\
\text { things as well. }\end{array}$ & 3.57 \\
\hline \multirow{4}{*}{ Brand } & Branded products are more expensive so I prefer to buy non branded products. & 3.09 \\
\hline & I would prefer to buy well known brand names online. & 3.78 \\
\hline & Branded Products motivates me to buy online. & 3.71 \\
\hline & I don't care about brand name while I purchase online. & 3.08 \\
\hline \multirow{3}{*}{ Quality } & $\begin{array}{l}\text { I always buy good quality products even though a cheaper version is available } \\
\text { as well with less emphasis on brand. }\end{array}$ & 3.5 \\
\hline & $\begin{array}{l}\text { The availability of high quality product/service provided by website is very } \\
\text { important to me. }\end{array}$ & 3.76 \\
\hline & Products available online are always of Good quality. & 3.19 \\
\hline \multirow{4}{*}{ Emotional } & I feel happy after doing online shopping & 3.87 \\
\hline & I like online shopping and I feel satisfied after making an online purchase & 3.52 \\
\hline & Internet shopping is enjoyable and I feel excited while purchasing online & 3.57 \\
\hline & Internet shopping gives me pleasure. & 3.54 \\
\hline \multirow{5}{*}{ Value/ Price } & Internet shopping provides best value for the money & 3.63 \\
\hline & Online shopping helps me to compare products and prices. & 4.2 \\
\hline & Spending excessive money on online purchase is not good & 3.68 \\
\hline & I plan my purchases carefully and only purchase best quality at lowest price & 3.93 \\
\hline & Discount / Cash back offers are major attractions for me to buy online. & 3.93 \\
\hline
\end{tabular}


Base of Calculation of Mean score: All the above statements were based on Likert Scale and the scale was given values from $5-1$ and then multiplied with no. of responses to find out the mean score.

\begin{tabular}{|c|c|c|c|c|}
\hline Strongly Agree & Agree & Neutral & Disagree & Strongly Disagree \\
\hline 5 & 4 & 3 & 2 & 1 \\
\hline
\end{tabular}

Interpretation: Above statements will be interpreted as per the shopping orientation which is as follows:

5.6.1 Impulse Purchase Orientation: From the 5 statements which were asked from these set of Consumers the mean score lies in the range of $3-4$ which clearly indicates that the respondents were agreeing to most of the statements wherein they felt good after making a purchase even though it was not planned. One major reason for this impulse buying is availability of huge discounts and various offers which excites them about purchasing something and they eventually end up buying those products.

5.6.2 Brand Orientation: Some disguised statements were asked from the respondents but almost all the consumers who belonged to this category were strongly related to their brands or in other words brand was more important to them than anything else irrespective of the price. They considered that branded goods have more quality and they give better value for the money.

5.6.3 Quality Orientation: Respondents were bit skeptical about the quality of products available online they felt that goods available online are not of good quality but also if a good quality product is available then they purchase the same.

5.6.4 Emotional Orientation: Respondents belonging to this category agreed with the fact that buying online made them feel accomplished. They felt excited on making a purchase and it gave them sense of happiness.

5.6.5 Value / Price Orientation: Among all other set of shopping orientations these set of consumers had a different thinking wherein they considered the price of product most important and whether that products gives them value for money or not. These types of consumers are always comparing different products on different websites and the product which is as per there taste and preference is added in the basket. They plan their purchases very carefully and are always looking for cash back or discount offers from the companies.

\section{Findings and Observations}

After analyzing the responses from 523 respondents following were the major findings:

1. E Commerce has been well accepted by Indian shoppers as most of the consumers have been buying online since more than 2 years and from observation it can also be said that these consumers are looking out for multiple products online and not sticking only to 1 category.

2. Another very important finding is consumers are getting more and more awareness about $\mathrm{E}$ Commerce through advertisements given by the companies and indirectly may be 
Government emphasis on cashless India and digital India are boosting E Commerce sector sales.

3. Word of mouth is another major finding wherein consumers are sharing their online purchase on social media which leads to indirect promotions for the companies.

4. Even though consumers have been purchasing since long but still they are not buying high value items as their average spending is only between $500-1500$ Rs.

5. There is another myth in Indian markets that people buy during sales and various festivals but from this research it was found that majority of people these days are buying only when they need something and the old tradition of accumulating things is not followed these days.

6. Among the 5 shopping orientations which were focused upon in this paper major findings were that consumers are mostly looking for branded products online and they also perceived that good quality products are not available online. Another very interesting finding is many consumers stated that they felt very happy and good after making an online purchase because they got huge discounts and value for money.

\section{Conclusion:}

From this research it can be concluded that E Commerce has brought a significant change in the mindset of consumers as how they perceive it and how they do their online shopping. Online buying has been well accepted by the Indian consumers and majority of them are making purchases whenever they need something. Still a doubt is there in the minds of consumers as to whether they will get the right quality product or not. So to eliminate same companies need to strengthen their customer care department and various promotional tools should be taken up so as to clarify those doubts.

Shopping orientation of a consumer strongly affects as to what they will buy and not. A consumer who is brand conscious will always go for a brand whatever the case may be irrespective of the price on the other side a consumer who is always on a look out for discounts and cash back goes for a value for money product which gives him/her maximum satisfaction. Then there are other set of consumers who are Impulse purchasers they don't make planned purchases but whenever they are browsing online they feel tempted to purchase online. In conclusion it can be said that irrespective of what companies do and what products they offer a consumers purchase intention is highly affected by the orientations he/she has. A company who is looking out for maximum sales online should do a proper research as to what the consumer is looking for and should try to retain that customer through proper promotional efforts.

\section{References}

Taweerat Jiradilok, S. M. (February 2014). The Impact of Customer Satisfaction on Online Purchasing: A Case Study Analysis in Thailand. Journal of Economics, Business and Management , 2 (1), 5-11.

Umair Cheema, M. R. (2013). The Trend of Online Shopping in $21^{\text {st }}$ Century:Impact of Enjoyment in TAM model. Asian Journal of Empirical Research , 3 (2), 131-141. 
Hosam El-Sofany, T. A.-M.-A.-A. (2012). Impact of Trust Factors in Improvement and Development of E-commerce in Saudi Arabia. International Journal of Computer Applications , 55 (9), 15-24.

Choon Ling Kwek, H. P.-C. (2012). Investigating the Shopping Orientations on Online Purchase Intention in the e-Commerce Environment: A Malaysian Study. Journal of Internet Banking and Commerce, 15 (2), 1-22.

Chee Wei Phang, A. K. (2010). Customers' preference of online store visit strategies: an investigation ofdemographic variables. European Journal of Information Systems , 19, 344-358.

Julian ming sung cheng, E. s. (2008). Why do customers utilize the internet as a retailing platform? a view from customer percieved value. Asia pacific journal of marketing and logistics, 21 (1), 144-160.

Kenneth C Gehrt, M. N. (2012). Emergence of Online shopping in India : Shopping orientations segments. International journal of retail and distribution management, 40 (10), 742-758.

VIJAYASARATHY, L. R. (2010, March 16). Shopping Orientations, Product Types and Internet Shopping Intentions. Retrieved June 28, 2015, from internetmarket.org: www.internetmarket.org

Mark Brown, N. P. (2003). Buying or browsing? An exploration of shopping orientations and online purchase intention. European Journal of Marketing , 37 (11), 1666-1684. 